American Research Journal of English and Literature

ISSN (Online): 2378-9026

Volume 4, Issue 1, 2018, 1-10 Pages

DOI:10.21694/2378-9026.18005

AMERICAN RESEARCH JOURNALS

An Academic Publishing House

\title{
A Psychological Analysis of Parental Favouritism and Hypocrycy of Family Love in Mansfield's 'New Dresses'
}

\author{
Md. Saiful Alam \\ Lecturer in English, Department of English language and Literature (ELL) \\ University of Creative Technology, Chittagong, Bangladesh \\ saifnottingham@gmail.com
}

Abstract: This paper deals with two affecting family issues: (1) "parental favoritism" and (2) "hypocrisy of family love" represented in one of Mansfield's best-known stories i.e., "New Dresses" (1912). The analysis of the issues is based on a couple of psychological considerations; i.e., "favoritism" and "hypocrisy of love" of parents. Parent-child relationship is a paramount exhibition in New Dresses. This study encompasses two basic questions: (1) how the themes of parental favoritism and hypocrisy of love are depicted in the story, (2) what consequences of these categories of stances of parents have in the family relationships. The present analysis comes up with a finding that Helen is a much -less favored child. But, her little brother, very affectionately called 'Boy,' and her younger sister, Rose, are her parents' favorites. Helen's parents show some sort of dislike towards Helen, and they justify it by pointing to a few of her flaws. However, Helen's parents' justification, at any rate, does not make sense to her grandmother. With a feeling of astonishment and shock, she observes that Henry and Anne, the parents, cause Helen's mental destruction by making unjustifiable excuses. Favoritism and hypocrisy of love of her parents result in a hostility between Helen and her parents. Consequently, this leads Helen to go to seek surrogate parents; e.g., her grandmother and Dr. Malcolm. Mansfield's attention towards her depiction of such issues as parental favoritism and parent-child relationships may have derived from her psychological tension about the contemporary parenting model; it may also have derived from her personal experience of the treatment that she received as a child from her parents. Ergo, this paper, too, briefly focuses on Mansfield's biographical facts, and often links them with Helen's scenario.

Keywords: Favoritism, parental favoritism, hypocrisy of family love, surrogate parents INTRODUCTION

Parental favoritism refers to a practice of giving unfair preferential treatment to one child over another. This practice is, to a higher degree, observed in Helen's family life in Mansfield's "New Dresses". Henry and Anne are the parents of three offspring; i.e., Helen, Rose and Boy. But, obviously the parents can't demonstrate equal treatment of love and care, and attention to all three children. They display additional degree of intense affection and love towards the Boy and Rose, giving less attention to Helen all the time in the same setting of family life under the same roof. Psychologists assert that favoritism or "playing favorites" is such a phenomenon that causes an adverse and often irreparable damage to the family relationships, and that it generates hostility among siblings and that it might foster aloofness between parent and child, all of which are also prevailing consequences in Helen's life and family. Now, hypocrisy of family love refers to parents' commitment of love for children and the inexistence of it in their real life activities and in their words while dealing with children. Although Helen's parents occasionally tend to show their unbiased treatment towards every children, and although they overtly claim that they love Helen as much as they do the other two children, they typically fail to provide enough evidence of the commitment in their activities and attitude toward Helen. Through their harsh, negative attitudes, they rather demonstrate the truth of their unavailability of the same amount of love as they show to the Boy and Rose. This inconsistence between words and actions does not conform to their claim of love 
A Psychological Analysis of Parental Favouritism and Hypocrycy of Family Love in Mansfield's 'New Dresses'

for Helen. Therefore, the parental approach of this type could be, in quality, considered to be hypocrisy of family relationships. Psychology further contends that if parents indulge themselves with favoritism and hypocrisy in child-parent relationships, it generates a long standing rancor not only between the parent and child, but often between the siblings. The context of Helen in "New Dresses" also fits what the psychologists say as we notice that she develops resentment towards her parents, and hostility with Rose and Boy. Such a representation of hypocrisy and favoritism of parents in Mansfield's fiction could be the result of Mansfield's firsthand experience of her lonely childhood, dearth of parental love, and austerity of parents etc. By her attention and surveillance to such family themes in her writings, Mansfield perhaps holds out a contemporary context of the unbefitting parenting pattern for a reappraisal, which still carries a 21st century social and familial relevance, too.

\section{MANSFIELD'S EXRPERIENCE}

Biographers often assume that Mansfield's childhood circumstances made her pay attention to writing about children and childhood in her fiction. Despite living in an extended family, Mansfield lived an estranged child. According to Hankin (1983), "Mansfield ... felt herself to be an unloved, even unwanted child" by her parents. The same childhood description is also echoed in Tomlin's (1980) words: "her (Mansfield's) life was essentially a lonely one." Behind this isolation was the mental and physical unavailability of her parents. Furthermore, her parents' 'favoritism', her 'birth order" and 'gender identity', and unattractive 'appearance' are said to be a few more reasons behind Mansfield's being unattended and less-noticed by her parents. Mansfield's father, Harold Beauchamp, was a self-made business man. His longing to be more in business turned him a very busy father: often away from home for business purposes, which created an ever absence of anxiety in Harold of building a father-daughter rapport. According to Mills (cited in Hankin, 1983), "... he (Harold) scarcely remembered Katherine Mansfield as a child - too much absorbed in building up business..." Boddy (1998) describes that at times, Mansfield's mother, too, traveled with her father, and they would leave child Mansfield in the care of her grandmother. Therefore, this frequent abundance by her parents, when she needs them, very normally creates a growing sense of loneliness in Mansfield. She is inwardly affected by the burden of forbearance of this parental absence from her child mind and from home, which she perhaps did not get anybody to share with. But, when she grew up and embarked on writing, she amazingly started unfolding her childhood days of deprivation from due parental love, care, and affection in her fiction. Mansfield's father was a middle class traditional father, and he was straightforwardly gender-biased. He had a committed directedness to a male child following the births of several daughters. It is for the cultural pattern of gender expectation of the fathers of Mansfield's time that her father was dying for a boy child. Because of this male preference, a boy child would receive more than due attention and love than a girl child in the same family. Mills (cited in Hankin, 1983) states that the son was "... loved by all-the hope of and heir of father." Accordingly, as per the prevailing practice of culture of that time, Mansfield's brother received their parents' preference, and she was a natural victim of 'favoritism'. Mansfield's birth order also partly influenced her alienated position amongst all the relationships, and she often felt inferiority because of the avoidance by her parents and siblings. Mansfield had a pain of (un)belongingness and of not becoming her parents' favorite, which perhaps had a link with her hostile personality and behavior towards her father and siblings. Margaret Woodhouse (cited in Hankin, 1983:5) states that Mansfield had a bitter resentment against her father. Woods states that (2012) after the birth of her brother, Leslie, the family fell into two groupings: "her elder sisters Vera (1885) and Charlotte (1887) formed the top natural partnership; and Jeanne (four years younger than Mansfield) and Leslie were the other group who were always called 'the babies'". Consequently Mansfield, Woods comments, found herself isolated in between with no particular allay of her own.

Further reason behind Mansfield's not being her parents' favorite was probably her less attractive appearance. Mansfield was not so attractive to look as her parents' favorite daughter, Vera, was. Meyers (2002) describes that in a childhood photograph Mansfield appears with a pinched mouth, pudgy face, and a severe, solemn look. Her mother looks at her with the traditional pair of eyes in which Mansfield is less precious than Vera in 
terms of outward appearance. Her mother does not find happiness, and she passes a discouraging comment at Mansfield's fatness when she returns home from England. So, all these negative look and frivolities of Mansfield's parents may have made the girl think otherwise about her parents; and it created some unhappy feelings between the child-parent relationships. According to Hankin (1983), "Mansfield had a psychological tension about her childhood experiences". All this is reflected through her bitter depictions of the 'favoritism' and 'unequal family love' in her stories such as 'New Dresses'. It can be said that in the story, Helen represents Mansfield as McRae (2000: viii) says: Mansfield constantly "goes in and out of her [character's mind]."

\section{AN ENCAPSUlation OF NEW DRESSES}

Mansfield's New Dresses (1922) is a quite a long story- much longer than some other stories- which is about the making of new dresses by the mother for Rose and Helen: the story highlights more on the parents' attitude disparity to the children mainly through the incident of dress making. Anne, the mother, makes new dresses for both of her daughters-Helen and Rose. The daughters' grandmother helps the dress making activity, as well. Anne gives Helen's dress to be sewed by the grandmother, and she urges her not to use any lace on Helen's cuffs because she thinks Helen is careless. On the other hand, Anne sews Rose's dress by her own hands with more interest, enthusiasm and euphoria as she treats the job as a really "substantial" assignment for her. She feels kind of interrupted while doing this job by the grandmother's harping. It is worth mentioning that the selection of the jobs of sewing dresses for Helen and Rose are basically intentional. In fact, Anne prefers doing things for Rose. The grandmother criticizes Anne for her regarding Helen as unimportant or inferior, and she thinks that Anne is ruining the child by her negligent way of behavior. In addition to Anne, Henry, the father, also appears to be similarly less caring about child Helen. He gets angry seeing the costly dress made for Helen. To him, to give a costly, beautiful dress to Helen is equal to making her indecent; besides it's a lavish spending which makes it difficult for him to buy gifts for his Boy whom he considers as his asset. In the course of events, Helen tears her frock. She hides the torn dress in a secret place. She invents a story that the dress is missing. Her father, Henry, comes to know of it, and gets furious. He reprimands her, and threatens to whip her next day after returning from office. Dr. Malcolm, Henry's family friend, observes this state of affair, and purchases a corresponding new set of dress for Helen without letting Henry and Anne know anything of it, and with the assistance of the grandmother he saves Helen from his father's promised punishment.

\section{LITERATURE REVIEW}

It is in the simplest sense that literature is the expression of life. As a writer, Mansfield never forgets this core function of literature. She accepted that literature is generated from the authors' real life experiences. Once she wrote: "... I think the only way to live as a writer is to draw upon one's real familiar life... (Boddy, 1996: 11)." Achiri (2014) states that a writer's personal life is inevitably reflected in his/ her literary works. Keeping with this biographical capacity of effect on Mansfield's writings, researches have been carried out over time on some issues in her fiction such as, father characters, mother characters, family, space, health etc. Woods (2007) comes up with a finding that the father character and mother character in Prelude (1918) and At the Bay (1922) are respectively self-important and indifferent, and distant. Drummond (1990) in his research shows that Katherine Mansfield's personal isolation, her relationships of family and friends, shift in life, space and health helped her develop and succeed as a writer in the world literature. This study unveils the relationships of the characters in the family in her fiction, which has relation to Mansfield's own life experiences. Margaret Woodhouse (cited in Hankin, 1983:5) states that Mansfield had a bitter resentment against her father, which is represented in her short stories including "New Dresses". However, the less-noticed and inadequately phenomenon is the parental preferential attitude to some child as a psychologically important theme in Mansfield's story of New Dresses. So far as known, there has not been any study on this specific theme which has an all-time familial, social, and psychological relevance - in the 21st century as well. This paper bridges this gap, which will add to the body of literature on Mansfield's studies.

American Research Journal of English and Literature

Page 3 


\section{PARENTAL FAVOURITISM}

Suitor et al (2009) define parental favoritism as a 'parent affect' and 'perceptions of parental preference' (cited in Caspi, 2011). In other words, parental favoritism refers to the fact that one sibling is more favored or less favored than the other by their parents. The belief about 'favorite' child actually started form favoritism - the unfair or unequal treatment of parents towards their offspring. However, favoritism can be at two levels i.e., (i) at perceived level or (i0 at really existent level. For example, you would expect a disabled sibling to demand more care, attention, and thoughts from parents. In this type of context, favoritism may exist just in child's perception but not actually in the parents' intention. Caspi (2011) makes it clearer by pointing to the situation: "'despite parents' best efforts to be fair, children may still believe favoritism exists." According to Kowal et al. (2006), when the reasons behind why differential treatment exists make no sensible and agreed impression in children, or when the occasions on which the explanation of differential treatment is not provided by showing parents' real sincerity, in that particular context children are most probable to make general perception of favoritism or injustice. It is a typical behavior of parents that they wave aside children's claims that they feel less favored. It may be decisively thinkable that favoritism may truly exist when child's claims of injustice are ignored by parents instead of their going through a process of self-criticism. Caspi, (2011) states that "ignored claims of injustice" are an important part of "evaluating favoritism". Libby (2010) accounts that the parents who show favoritism very often justify their unequal treatment and give reason that the more favored child is prettier than the lees-favored or less-cared child. Cross and Stewart (2007) point to some particular reasons that might posit parents' favoritism. They connect favoritism to "children's traits" such as, blaming others; being perfectionist and manipulative; avoiding conflicts, and being precocious etc. They also opine that "children's temperament" is one more thing that makes parents assume good feelings and trust in some child, and bad feelings and inattention in some other child. It typifies when the situtaion is that a child is negative and picky, it receives smaller amount of attention from parents; it encounters more avoidance or criticism from them; while an easygoing, positive, and happy child, in total contrast, is recognized with more love and liking by the parents. The third issue that has an effect on favoritism is "parents' own needs" which is, Cross and Stewart believe, very unhealthy and inappropriate for child-parent relationship. For example, a mother might have more caring feelings towards a son for the reason that her husband can't meet some of her needs. The last but not least, Cross and Stewart state that child's "physical appearance" sometimes but not always leads to biased treatment by the parents towards children. As a matter of fact, Cross and Stewart come up with many manners of parents in which parental favoritism can be displayed. Some are given below:

I. When parents introduce their children to relatives or friends, they often say something mixed with excitement and voice inflection and enthusiasm, such as: "this is our straight-A Child". It may give a premonition of favoritism.

II. When parents' discipline gives impression that they are more lenient to one child than to the other, it exhibits their favoritism.

III. When parents' conversational activity with one child is more engaging than with the other, favoritism in that context becomes obvious.

IV. When parents give more, better or costlier gifts to one child, the other may take a notice of it as favoritism.

$\mathrm{V}$. When parents are more disapproving of and bad about one child over the other, favoritism, in this event, becomes obvious.

VI. When parents prefer more affectionate names and addressing to the more favored child and use critical and insulting names to the other, favoritism is taken for granted.

As far as the consequences of parental favoritism are concerned, they are always badly affecting and destructive for the family relationships - parent-child relationships and the relationships between siblings. It splits the 
A Psychological Analysis of Parental Favouritism and Hypocrycy of Family Love in Mansfield's 'New Dresses'

family members into groups, and it sometimes creates new polarizations of relationships within and beyond the family. Evans \& Evans (2006) state that playing favorites can be very destructive for the family. Cross and Stewart (2007) consider favoritism as an "anger generator" in the children. Not only does it make the less favored child unfriendly, and aggressive towards his /her parents but also it may end up having a feeling of jealousy and hostility between siblings. Rhodes (2012) explains that the less favored child might have strong feeling of dislike or anger towards her / his parents and if he / she can't challenge his /her parents in a direct manner, he/ she can express the angry feelings by doing some action in an unprecedented and unpredictable way. Again, the less favored child might want to displace this anger onto her/ his siblings as well.

\section{HYPOCRACY OF FAMILY LOVE}

In the simplest sense, "hypocrisy of family love" represents the commitment of love between family memberslove between father and mother; sister and brother; brother and brother; sister and sister; parent and child etc.- but when this commitment of feeling of 'I love you' reduces to only words, not in their actions to each other, it is then labeled as hypocrisy of family love. Family love falls down its trust level, and they have a feeling that they actually don't love. In psychology, a hypocrite parent is he who wants their child to do what they themselves do not do. That is to say, the parental hypocrisy is a "marked contrast" between what they do and what they want the child to do. In that sense, the idea of 'hypocrisy of family love' becomes obvious in the perception that parents want their children to love them but they themselves don't return love to the children. It may be also interpreted that parents are hypocrites if they claim they love their children, but they prove in their actions and behavior that they actually don't. In practical consideration, children follow through on their parents. Reasonably, if the parents do not behave gently with the children and if they fail to prove sufficient love for them, they can't expect their children to give them due return of love and respect. Cobbett (2014) says that parents do not have right to get affection and love form children if they neglect them because it is essentially a level of hypocrisy in the family.

\section{ANAlysis OF 'NeW DRESSES'}

If carefully noticed, just from the very second paragraph, the theme of "parental favoritism" starts coming up in New Dresses. From the conversation that takes place between Helen's mother and grandmother on the issue of unequal design and styles of the dresses for Rose and Helen, the mother may be perceived as having favoritism towards Rose. The grandmother character notices, gets astonished by, and off and on protests this unequal treatment by Anne, the mother of Helen, Rose and Boy. Anne makes Rose's dress by her own hands leaving Helen's one to be done by grandmother. Her pre-occupation with Rose's dress might be endorsed as her particular parental interest to a particular child. Anne bluntly puts it that her garment work done for Rose is a lot more important than for Helen. She considers her job of making Rose's dress to be a "really substantial" one which might not be perfectly accomplished if the grandmother harps on things near Anne's ears. Aloud she said: "Mother, I'm having a really substantial hem in this dress of Rose" (Mansfield, 1924:92). But, Anne is not seen to worry about and to have enough eye on Helen's dress because Helen is not equally felt, cared and loved as Rose. This can be overtly Anne's parental favoritism given to Rose over Helen. In the conversation, Helen's mother wishes the grandmother not to put any lace to Helen's dress because she has her opinion that it will make a clear difference between Helen and Rose. She says: "And don't put any lace on Helen's cuffs; it will make a distinction" (Mansfield, 1924:92). On the surface level, it might suggest that Helen's mother desires Helen and Rose to be looked at equally. But, in deeper sense, it actually contrasts as she uncovers, in the later sentences, that she is annoyed at Helen. She more emphasizes on her "carelessness" rather than on the intention of being fair in treating both the daughters. In grandmother's view, "distinction" is merely an "excuse"; Anne is , in fact, playing favorite with Rose, putting aside Helen with dislike, and, little care and attention. Parental favoritism, thus, becomes obvious from the choice of design of dresses. As sated earlier, Cross and Stewart (2007) point to 
A Psychological Analysis of Parental Favouritism and Hypocrycy of Family Love in Mansfield's 'New Dresses' the issue of choosing dresses for children by the parents in which there can be the traces of parental favoritism. As Libby (2010) asserts, parents often allow themselves to justify their biased actions and words towards one child. Correspondingly, Helen's mother justifies her characterized absence of attention to Helen's dress's beauty by giving reason that Helen is a "so careless" daughter. She says: "...besides she's so careless about rubbing her hands on anything grubby" (Mansfield, 1924:92). If put into the words of Cross and Stewart (2007), Helen's mother's preferential treatment towards Rose over Helen is fundamentally due to the divergence of "child traits". Anne notes the dissimilarity between two daughters and her perspicacity makes the considered decision that Helen is inferior to Rose and, therefore, there is no warrant for as much serious attention and consideration for Helen as Rose deserves, which could be interpreted as inappropriate for a mother. It is in Grandmother's principle that Anne's justifications are too poor to allow herself to be prejudiced for Helen. The grandmother holds an opinion that Henry and Anne identically disparage Helen, and this is their confirmed gratuitous favoritism. She can't perceive the reason why the parents have a feeling of distance and hostility towards Helen. She "wondered why Anne had such a down on Helen - Henry was just the same. They seemed to want to hurt Helen's feelings - the distinction was merely an excuse" (Mansfield, 1924:91). Anne juxtaposes the state of affair of 'Black' of the dresses of Helen and Rose. Helen fits in the less favored on the rationale that she makes her dress dirtier than Rose does hers in a week. It is explicated that the child to whom her parent feels antipathy is likely to be subjected to favoritism even for a minor shortcoming of the child, which is seemingly germane to Helen's case. Anne also accounts for her less fondness for Helen by justifying that Helen is a "blithe" type of daughter. She shows her "uncaring countenance" when she is asked to be answerable for her "peccadillo". Anne is fed up with Helen's "stuttering" every time she is questioned about her faults or failure. She "shrugs" in response to her mother's aggressive questioning. Anne threatens to take her to Dr. Malcolm to give her a "good fright". So, from this inclination of punitive action, one thing may be manifest that Helen was not in her mother's good book, and she was not liberal enough about Helen to pass over her "foibles" from an understanding mother's aspect. As expounded by Cobbett (2014), Anne predisposes Helen to "shrug" as a return from the daughter for whom she is an epitome of frightfulness. In other words, Helen's mother's blinkered attitude of favoritism and hypocritical parenting approach may have, as sated Cross and Stewart (2007), ushered Helen to "anger" or "hostility" to her mother. Hankin (1980) vindicates that Helen's "stuttering" is an implied ancillary activity of her "challenge" to her mother's favoritism and hypocrisy of love. For Anne, Helen's stuttering is nothing but an affectation, which suggests that Helen uses 'stuttering' as a premeditated psychological contrivance to articulate her anger towards her biased mother. The grandmother being in the mantle of surrogate mother of Helen spares no effort to stand stricture against Anne; she lets her know that if "stuttering" is Helen's "misdemeanor", Anne is to be equally incriminated as a bad child because she herself had the very same problem of stuttering when she was in Helen's age.

Anne tries to persuade the grandmother that Helen lacks the understanding of her mother's being an 'egalitarian' in terms of her treatment with Helen and Rose. She sets forth: "She (Helen) is treated exactly like Rose"(Mansfield, 1924:92). Nevertheless, in the next moment, she makes it clear through her words that she is bringing up Helen with less care and love than the Boy and Rose. She points to the flaws in Helen that she has a nerve unlike the Boy, and she is not as "perfect" as Rose. Graver than this is Helen's shortcoming that her treatment to the Boy who is "Henry's obsession" (Hankin, 1983) is, to a great degree, off-putting. Anne also justifies her dislike of Helen by fingering at "the peculiar way she (Helen) treats Boy, staring at him and frightening him as she does" (Mansfield, 1924:92). The grandmother is not convinced by what all Anne brings in her argument about her apathy to Helen. In her ultimate appreciation, both the father and mother of Helen are going with favoritism towards the Boy and Rose depriving Helen of her equitable share of parental love and affection, the consequence of which is also identified and observed by the grandmother. Listening to Anne's 
A Psychological Analysis of Parental Favouritism and Hypocrycy of Family Love in Mansfield's 'New Dresses' reasoning, the grandmother remains mute for some moments, as likely as not, for assessing the issue with more internal attention, and what comes in her discernment and appraisal is that Helen's parents are, by their favoritism, just "ruining" her. Such a scenario of Helen's deprivation and the trauma caused by her parents who are hurting her feelings is right caught in her grandmother's eyes, but it never comes in her parents' realization. This unnoticed want of parental love caused by the parents' preference to the other two children ultimately results in a sibling antagonism as a consequence stated earlier by Evan (2006). It is Anne's own testimony that Helen frightens the Boy, which may be, as Rhodes (2012) states, the displacement of Helen's anger to her sibling. For Hankin (1983), it may be because of her rancor towards her parents, and it could be a plausible protest against parental favoritism as well.

In one or two more places, it further becomes evident that Anne loves and likes Rose more than she does Helen. The discrepancy of her enthusiasm in making Rose's and Helen's dresses reveals the disparity of her attitude towards the two daughters. She feels it is "useless to be tiring herself out with fine sewing for Helen" (Mansfield, 1924:94). She also feels ill at ease when the grandmother makes her point about Helen because the grandmother's justification of equal treatment for Helen from Carsfield and her creation of "touchiness" on the subject seem "absurd" to Anne. Anne quibbles about Helen's lack of "gratitude" that she is supposed to express to her mother as she does things for her. May be, thankfulness is a cultural pattern but a mother's deeds for her children should not always wait for appreciation or for any return from them. It may not be acceptable that Anne does not like Helen just because she is not thankful. If so, it is then equivalent to the severe penalty for a slight shortcoming being more of a child trait. Anne, the mother, ostracizes Helen from her siblings and "she was determined to keep Helen from the Boy" (Mansfield, 1924:95). This is from the parent's side that an intentional act of dividing the children in groups - favored and less favored- deteriorates relationships within the family. After such a favoritism of horrible level, Anne's claim that "Helen is treated just like Rose (ibid)" does not hold water and as stated earlier, it may be deemed to be the parent's hypocrisy of love.

With regard to the aspect of favoritism, Helen's father also does not fall behind her mother. He patently displays his inclination for his Boy and prejudice against his daughter, Helen. His vehemence of buying a chair or anything else for his Boy preoccupies his mind bestowing meager room for emotional rumination about Helen. As stated by Libby (2010), the parents who are in the position with more approbation to one child but with paucity of regard and fondness to another often resort to their own justification of their disparate feelings. Likewise, Helen's father in his wife's fashion puts forward an "excuse" to defend his distant deportment to Helen. His notion is that the method of keeping Helen "decent" is not to present highly priced dresses, and thus the issue of dresses , according to Cross and Stewart, gives vent to his favoritism.

Dr. Malcolm becomes aware through his observation of the fact that Helen is affected by her parents' preferential treatment. As Dr. Malcolm can comprehend that there is a suggested justification found in Helen's parents' remarks for disapprobation towards Helen, he speculates that it may be a mere redundant act to want to warn them of their unfair dealings with Helen. Instead, being a doctor, he feels a worry about Helen and cannot avoid her deprivation. He, therefore, comes forward as a surrogate father and builds up a rapport with Helen. In Helen's life, Dr. Malcolm becomes somebody after her grandmother in whose presence she feels "good", and with whom she feels confident to share her reaction to her parents' favoritism, which may be summarized in her words of " far worse" and "hellish".

As Cross and Stewart (2007) assert, biased parents call favorite child by adoring name and the less favored one by disparaging name. Henry calls his son as 'Boy' which is a mark of obvious dearness, but he counts his daughter Helen as "Plague" which is a comportment of a father of favoritism. Dr. Malcolm catches sight of 
A Psychological Analysis of Parental Favouritism and Hypocrycy of Family Love in Mansfield's 'New Dresses'

Helen's mother's discriminatory way of looking at her daughters. She compliments Rose's dress and appraises her color to be superior to Helen's: “Well, it really is Rose's color, said Anne. Her complexion is so much more vivid than Helen's" (Mansfield, 1924: 108). As pointed out by Cross and Stewart (2007), it is a commonplace way of the demonstration of favoritism that is performed by the parent while presenting their favorite child to strangers.

As sated by Evans and Evans (2006), the favoritism shown towards Rose and the Boy results in the 'anger' generated in Helen. Hankin (1983) elucidates that Helen's deliberate acts of tearing the new dress, negligence to it, hiding it etc. are the mark of determining her hostility towards her parents. She no more regards her parents. When Dr. Malcolm warns of the consequences of her speaking ill of her parents, Helen replies: "... so it doesn't matter. It's only with them I feel funny" (Mansfield, 1924:110). Helen is quite able to discern her parents' hypocrisy of love, and it makes her assume a disrespectful demeanor towards them. She makes fun of them in her mind, which may be held to be, as Rhodes (2012) sates, a dislike or a silent challenge to her parents. Furthermore, this favoritism leads Helen's anger to her siblings, as well. Anne complains that Helen scares her son, which is, according to Rhodes, the result of Helen's state of being unable to absolutely challenge her parents' favoritism. When Henry asks Helen: "You love your father and mother, don't you?" (Mansfield, 1924:118), she does not answer, which might be deemed as her unspoken protest against her parents' favoritism and an inward sarcasm to their hypocrisy of love. As Cobbett (2014) sates, Helen perhaps silently argues that love only returns love, which is not the case between her and her parents. Parental favoritism makes Helen disobedient and unfriendly, and the family divides into groups, which is corresponding with Mansfield's own life experiences, too. Mansfield was not so 'perfectly obedient' (Meyers, 2002) like her all other sisters. She was 'anxious, strung and rebellious' (ibid). It may be assumed that type of personality, nonconformity to other family members' thoughts and ideas about the ways of life and world provoked the 'parent-child alienation'(Middleton, 1966). If put in Kimber's (2016) words, it may be said that "Mansfield was a lonely child, not really fitting the pattern her parents wanted". Helen is grouped with her grandmother while the rest make the other group in the family so she is all but lonely, too. Therefore, it may be assumed that Mansfield's literary talent made the story of New Dresses but her real life family experiences made the characters of Helen, Anne, Carsfield, Boy, Rose , grandmother, and Malcolm.

\section{CONCLUSION}

In this study, an analysis of the parental favoritism and hypocrisy of family love in Mansfield's "New Dresses" is carried out with a view to seeking the answers to a couple of clearly defined questions - (1) how the themes of parental favoritism and hypocrisy of family love are depicted in the story, and (2) what are the consequences of it in the family relationships. The analysis shows that the parents -Henry and Anne - are almost uniform in terms of preferential treatment towards their children. They "play favorites" towards two children i.e., Rose and the Boy. But, they show less approval and preference to another child who is Helen. This favoritism is not to be assumed by the readers because it is categorically recognized and pointed out by the grandmother character. The analysis also shows that Helen's "child traits" result in the attainment of less heed and consideration from her parents. Anne, Helen's mother, points out the traits such as, "carelessness", "uncaring countenance", "stuttering", "shrugging", "lack of gratitude" etc. as Helen's negative child characteristics. Anne justifies her "disparity" of attitude to children although the grandmother dismisses all these as inadequate to be "excuses" for favoritism. Favoritism is obvious in terms of 'dresses', 'addressing and names', and 'gender'. Anne, the mother, is pre-occupied with Rose's dress with particular interest and considers her job of making Rose's dress "really" substantial while she does not have enough eyes on Helen's dress. In her eyes, as a child, Helen is not as "perfect" as Rose. Helen's father considers the spending on Helen's dress as "making her indecent" and as "lavish" expenditure while he shows his intense interest buying materials for the "Boy", his favorite. The analysis 
A Psychological Analysis of Parental Favouritism and Hypocrycy of Family Love in Mansfield's 'New Dresses' further maintains that in the "locution", and "actions" and "reactions" the parents substantiate hypocrisy of love. Anne avers that she does not make any "distinction" between her daughters, and she claims she "equally treats" Helen and Rose, but she overtly displays her favoritism to Rose in words and actions, which may be a mark of hypocrisy. Henry has a desire that Helen love her parents but his dislike towards her begets "dislike" from her back towards him. Thus, the series of events of parental favoritism and hypocrisy of family love gradually turn out to be a vehicle of "ruining" Helen. It has caused "antagonism" between Helen and her parents. In seeking to correct her, Helen's mother takes into account of giving " a good fright" to her while her father promises to "to whip" her. In reaction, Helen assumes "disregard" and "unfriendliness" towards her parents. She does not care them anymore as she says “...doesn't matter". Her mother feels that talking about Helen is "absurd" and sewing dress for her is "useless". In protest, Helen "shrugs" and "stutters". Her father calls her "plague" and Helen, in response, thinks up describing her parents' behavior as "hellish" and "far worse". And, feeling this to be not enough, Helen displaces her "anger" to her sibling, the Boy. She scares him. Ultimately, the family divides into groups- Henry, Anne, Boy and Rose versus Helen and grandmother. Helen feels estranged and ostracized by her parents. Feeling morose and uncomfortably confined by the lack of indispensable attention from her own parents, Helen's tender mind directs its attention to look for surrogate parents. She builds up a good rapport with Dr. Malcolm whom she assesses as a "most beautiful man" and only with him she feels "good". Dr. Malcolm comes up to save her from her father's impending punishment with the help of the grandmother who represents Helen's substitute mother. Although there is no one to one connection, Mansfield's childhood experiences, to some extent, may have an interconnection with Helen's exposition. And Mansfield very likely wanted to give a bounce to the contemporary parenting model and remodel the family life, which still has an undeniable relevance to the 21st century family traditions and parental shortcomings of bringing up children.

\section{REFERENCES}

1. Caspi, J. (2011). Sibling aggression: Assessment and treatment. Springer Publishing Company.

2. Kowal, A. K., Krull, J. L., \& Kramer, L. (2006). Shared understanding of parental differential treatment in families. Social Development, 15(2), 276-295.

3. Libby, E. (2010). The favorite child. Amherst, N.Y.: Prometheus Books.

4. Cross, R., \& Stewart, E. (2007). How we make our kids angry. Downers Grove, Ill.: IVP Books.

5. Evans, A., \& Evans, T. (2006). The Kingdom Agenda: What a Way to Live!. Moody Publishers.

6. Rhodes, L. (2012). The essential guide to caring for aging parents. New York, NY: Alpha.

7. Cobbett, W. (2014). [Twelve Sermons, on 1. Hypocrisy and cruelty. 2. Drunkenness, etc.]. London: Printed by B. Bensley, Andover, and published by the Author.

8. Meyers, J. (1980). Katherine Mansfield. London: New Directions.

9. Middleton, B. L. S. (1966). Alienation in the life and works of Katherine Mansfield (Doctoral dissertation, Rice University).

10. Kimber, G. (2016). Katherine Mansfield: The Early Years. Edinburgh: Edinburgh University Press. 9780748681457

11. Mansfield, K. (1924). Something childish and other stories. Lulu. com.

12. Drummond, W. (1990). A psychosocial study of Katherine Mansfield's life. Early Child Development and Care, 55(1), 89-98.

American Research Journal of English and Literature

Page 9 
A Psychological Analysis of Parental Favouritism and Hypocrycy of Family Love in Mansfield's 'New Dresses'

13. Achiri, S. (2014). The Transcendental Selves of Women Characters in Katherine Mansfield's "At the Bay": The Case of Linda. International Journal of Applied Linguistics and English Literature, 3(6), 98-101.

14. Boddy, G. (1988). Katherine Mansfield: The woman and the writer. Ringwood, Vic., Australia; New York, NY, USA: Penguin.

15. Woods, J. (2007). Katherine Mansfield, 1888-1923. Kōtare: New Zealand Notes \& Queries, 7(1).

16. McRae, J. (2000). Introduction. In K. Mansfield, The garden party and other stories: Stories finished and unfinished (pp. vii -xiii). London: Penguin.

17. Boddy, G. (1996). A 'Do you remember' life. Wellington: Victoria University Press with the Katherine Mansfield Birthplace Society.

18. Suitor, J. J., Sechrist, J., Plikuhn, M., Pardo, S. T., Gilligan, M., \& Pillemer, K. (2009). The role of perceived maternal favoritism in sibling relations in midlife. Journal of Marriage and Family, 71(4), 1026-1038.

Citation: Md. Saiful Alam, "A Psychological Analysis of Parental Favouritism and Hypocrycy of Family Love in Mansfield's 'New Dresses'”' American Research Journal of English and Literature, vol 4, no. 1, 2018, pp. 1-10.

Copyright (C) 2018 Md. Saiful Alam, This is an open access article distributed under the Creative Commons Attribution License, which permits unrestricted use, distribution, and reproduction in any medium, provided the original work is properly cited. 